Information Management and Business Review

Vol. 3, No. 3, pp. 133-138, Sep 2011 (ISSN 2220-3796)

\title{
Mentoring and its Effects on Turnover Intensions in Perspective of Pakistan's Telecom Sector
}

\author{
Syed Saad Hussain Shah ${ }^{1}$, Jabran Aziz ${ }^{1}$, Ahsan Raza Jaffari ${ }^{1}$, Muhammad Wasiq Ejaz ${ }^{1}$, Asad Khattak ${ }^{1}$, Kashif \\ Ur Rehman¹, Muhammad Aslam Khan² \\ 1'Iqra University, Islamabad Campus, Pakistan \\ 2Preston University, Islamabad, Pakistan \\ *John.ellia@gmail.com
}

\begin{abstract}
In today's era of towering competition the retention of workforce is highly desirable for long term success of any organization. The employees serve as backbone for any organization and are responsible for attaining the laid down objectives of the organization. The ongoing study investigates the effects of mentoring on turnover intensions of employees working in telecom sector of Pakistan. Researchers retrieved data with the help of questionnaires based on five point likert scale from almost 300 employees working in telecom organizations of Pakistan. Multiple regressions were used to analyze the collected data. Result shows that mentoring mostly is negatively associated with turnover intension because employee was not satisfied with mentoring and commitment in employees is only due to experienced learning which helps to develop additional skills in employee.
\end{abstract}

Keywords: Mentoring, organization commitment, turnover intensions, carrier development, Strategic Human Resource Management.

\section{Introduction}

Employees are the most valuable assets of the organization. They contribute to the organization in many dimensions. It is strongly believed that satisfied employees have a big share in the success of the organization. Capital is the most important resource of the organization. Without reasonable capital the development is very difficult. Same is the case of technology. Every organization in this fast growing world would give priority to the use of latest technology. Without induction of committed employees, it is not possible to achieve efficiency. Employees create value of the organization. Employees bring fresh ideas to the organization which may help the organization for future growth.

A lot of focus has been put on management performance of the organizations for making the high organizational effectiveness. Usually when employees leave the organization, it creates restlessness in the organization. It may increase the cost of the firm. When the turnover rate of any organization is high, the employee's attitude is not positive. The standard of organization is also considered low as compared to its competitors. An employee must be satisfied with the job conditions. It is strongly believed that job satisfaction plays an important role in gaining the competitive advantage of the firm (Barney, 1991; Pfeffer, 1994). Employees perform better in the comfortable atmosphere. Work system of organization is positive when the employees are satisfied from the practices of the organization. Workplace values performance positive role in employee's satisfaction.

The career development of the employees means the planning used for matching the career goals of individuals with business goals. A well defined career development plan is considered useful for employees who are committed to the organization. When the employees feel dissatisfied on the job, they need a mentor to keep their wills alive. The constant communication with mentors improves the retention rate at the job. Zakaria and Yusoff (2011) highlighted the transformation of human resources into human capital by attracting and attaining the employees to meet the strategic goals of the organization. In current research the impact of mentoring is observed on turnover intensions of employees of Telenor sector of Pakistan for the first time. Few new variables i.e., experienced support and experienced learning has been added to the model. 
This model is tested in Pakistani environment which reflects the nature of training and development in this region and it can be compared with the western countries.

\section{Literature Review}

Turnover Intension: Turnover either can play a negative role in organization reputation. Some time the employees may switch to the better organization for their career development. Some time the employee may feel that the perks and facilities provided by employer and the future development chances are rare and he may quit the job (Phillips, 1982). If an employee leaves the job, some better employees can be hired as their replacements. Turnover intention is assumed to be the feeling of an individual employee towards his staying or not staying in the organization (Cotton and Tuttle, 1986).

In any profession turnover intension is the act of leaving the existing job by an employee (Chaplain, 1995; Sari, 2004). Several researchers have found that employee only leaves the job when they are not satisfied with their employers (Olian et.al, 1985). Generally, these employees are satisfied in routine life (Gibb and Megginson, 1993). Satisfied employees rarely quit the job (Morrison and Von, 1990). While many research studies found that dissatisfaction is caused when there is over burden on employees (Ragins and Cotton, 1991).

Mentoring: Professional learning is critical for the employees and the best method is of course by assigning a mentor (Carter, 1994). For this purpose the role of mentor and the relationship among mentor and mentee is important (Ragins and Scandura, 1994) they need each other's support for the success of the program. Mentoring is a tool with which high cost of turnover can be reduced. However, the research already made shows mixed result (Megginson et. al, 2006).

Career development

Career development programs can reduce the turnover intension among employees. Basically, turnover leads to high cost including direct costs like recruitment, selection, and training of new people. Much time and expense go into this process (Swickert et. al, 2002). It is believed that progressive HR practices and career development programs can contribute to reduce the turnover intensions among the employees (Huselid, 1995). Career development provides benefits to both employers and employees (Lips and Hall, 2007). If an employee feels that his career development is going towards positive side, it in turns attention to development issues can affect an organization's retention rates of both its domestic and its global employees (Scandura, 1992).

Experienced Learning: Continuous learning is important for the employees to cope with the latest development inside the organizations by having a mentor which shows them directions (Xianting and Fungfai, 2010). Mentors provide experienced learning as develops team learning approach, secondly visions are shared, make models based on mentality, helps to identify personal mastery and aid in thinking systematically (Senge,1990). It is the need of era to focus on improving the knowledge of worker and increase their performances by having closer eye on the transference of knowledge (Xianting and Fungfai, 2010). To meet the needs of tactical goals it is, must to ensure smooth transfer of knowledge and identify continuous learning method (Pedler et.al, 1991). In this aspect mentoring is necessary as it facilitates employee to indulge in seeking more knowledge continuously and mark their workforce as a valuable asset for the organization (Xianting and Fungfai, 2010).

So organization should be of such type where there is a continuous learning process for acquiring more knowledge and willingness to applicability of this knowledge aid in decision making (Templeton et. al, 2002).

Learning organization to give experienced learning to employees has been viewed in different terms in other researches too as learning processes are taken into analysis account and gets monitoring, management and made to inline the creativity goals and improvement to meet organizational objectives (Gephart et al., 1996). Furthermore this experienced learning is viewed from an organizational perspective as a three key system consists of level at systematic procedure, a learning process development on continuous improvements and 
managed in such a way to build results in term of knowledge that leads to achieve organizational efficiency (Marsick and Watkins, 1999).

Experienced Support: Mentoring aids in improving the support of employees so that they can get settled in their latest tasks and always try to provide them advice to excel their efficiency (Bryant and Terborg, 2008). Mentoring can be provided as an experienced support in two forms, first form is informal mentoring where mentors aid employees in direction and recommendations and meets him in informal contact (Leslie et al., 2005) but informal mentoring is not as much considered rewarded by the organization (Xianting and Fungfai, 2010). On the other hand formal mentoring aids to give assistance from diverse mentors within the scope of company (Dawn and Palmer, 2009) as these sort of mentoring are more advantageous as informal mentoring because mentee enjoys advancement in careers, his turnover intentions get reduced and starts to build and expand circle of knowledge sharing that results in increased promise to get committed with the organization and guarantees success (Leslie et al., 2005).

More over extrinsic benefits are also associated with formal mentoring as when employees start to perform well, increased leadership professional skills, develops good interpersonal relations' among peers, started to advance career goals and becomes confident resulting in the increasing the pace of output (Leslie et al., 2005; Megginson et al., 2006). Experienced support result in producing formal mentoring programs in having strategic beneficial fit between the two i.e. mentor, mentee and organization as in contrast to informal mentoring technique as it is only beneficial in view of person having training from the mentor (Klasen and Clutterbuck, 2001). Employees career aspirations should be in line with the future of organizational needs and experienced support should be provided to increase in human property (Baruch, 2006).

In view of promotions, motivation, incomes, work satisfaction these factors increases by having a mentor and on other hand these factors are viewed in lower context if mentor is not present (Ragins et. al, 2000) as increased dedication to organization has researched by various researches having a mentor (Allen et.al, 2004; Laukau and Scandura, 2002; Lentz, 2004; Ragins et. al, 2000) shows less pace to turnover intention (Lentz, 2004; Lentz and Allen, 2009) boosting performances on job (Lentz, 2004; Levenson et. al, 2006). Nevertheless some researchers found it exactly opposite by having no major relations with the mentoring process and objective to switch job (Allen et al., 2004) and performance on the job (Van , 2008).

\section{Theoretical Model:}

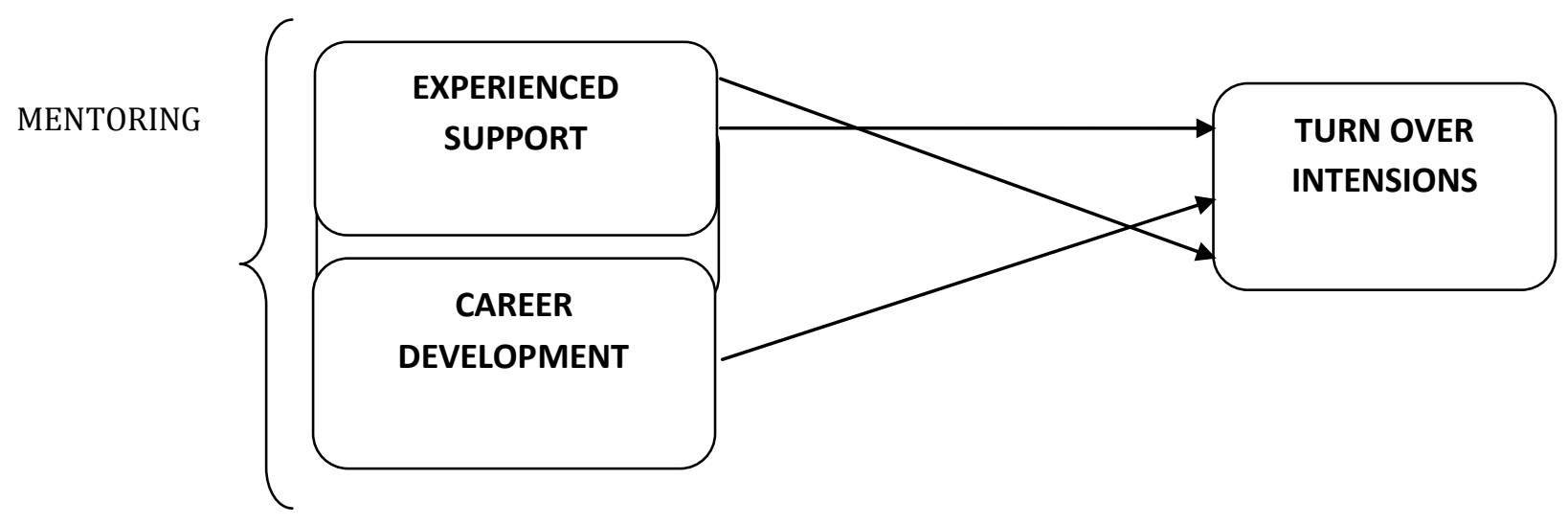

\section{Hypotheses}

H 1 - Experienced support from mentors that is given to employees has a positive impact on employee's turnover intensions.

H 2 - Experienced learning environment that is created by mentors for the employees has a positive impact on employee's turnover intensions.

H 3 - Career development has a significant positive impact on turnover intensions of employees. 


\section{Methodology}

The study was conducted among the employees of Telecom Sector of Pakistan. The telecom companies that are operating in Pakistan are multinationals. Data collection has been divided into two stages where first stage consists of pilot study based on 100 respondents. However, the second stage consists of a broad study where a large number of customers are selected as sample which includes direct distribution and mailing through emails and registered posts. The survey was distributed to around 400 customers. The instrument was developed using Five Likert-type scales.

Procedure: To analyze the data SPSS software was used where result obtained was found to be significant. Furthermore eight outliers were removed from the questionnaires and the remaining questionnaires were correct.

\section{Results and Discussion}

A total of 300 respondents completed the questionnaire. The average respondent was 35 years of age, and had 14 years of education. Out of 300 respondent 260 were male that is $87 \%$.

Table 1: Regression Results: Co-efficient, Parenthesis (Standard Error), Brackets (t-value) and in italic (P-Value)

\begin{tabular}{cccccc}
\hline Constant & $\begin{array}{c}\text { Experience } \\
\text { Support (IV1) }\end{array}$ & $\begin{array}{c}\text { Experienced } \\
\text { Learning (IV2) }\end{array}$ & $\begin{array}{c}\text { Career } \\
\text { Development (IV3) }\end{array}$ & R Square & F \\
\hline 4.844 & -.394 & .549 & -.541 & 0.876 & 344.821 \\
$(.056)$ & $(.032)$ & $(.022)$ & $(.038)$ & & \\
{$[86.108]$} & {$[-12.480]$} & {$[24.583]$} & {$[-14.073]$} & & .000 \\
.000 & .000 & .000 & .000 & & \\
\hline
\end{tabular}

The outcome of values marks coefficients $\beta$ of individuals highlights that the result is significant and positive if viewed from broader perspective. Research indicates the dependent variable turnover intention has deep relation with experienced support, experienced learning \& career development i.e. the independent variables as regression values are greater in number as compared to residuals value as observed in SPSS test. However the first independent variable experienced support shows a negative relationship with the dependent variable i.e. turnover intention. While the second independent variable i.e. experienced learning shows a positive relation with the dependent variable. Third independent variable i.e. career development again shows a negative relationship with dependent variable.

$\mathrm{R}$ Square 0.876 shows that the model is a fit one and $87.6 \%$ variation in the dependent variable; turnover intention, is because of all the independent variables. Whole analysis shows that the variables Experienced support, Experienced learning \& Career development which is independent in nature influences Turnover intention of employees and gives a significant result as $\mathrm{P}<.05, \mathrm{~F}=344.821$ and the $\mathrm{R}$ Square $>.70$ whereas the standard error $<1$.

\section{Conclusion}

Based on the above research our study finds that the support to employees from mentors are not up to the mark in minds of employees, secondly same goes for the career development where employees feel that mentors are not assisting them for their career advancement goals, However employees have opportunities to learn and polish their skills but mentor assistance is not meeting up to their expectations. 
Limitations/Further Research: There are certain limitations to the study which needs to be mentioned here;

- The sample size of our study is low, so it cannot be generalized so further it can be done by bigger sample size having a bigger focus.

- The results can be tested by adding new variables to the model e.g. informal training, couching, on the job training etc.

- This study was conducted purely with the employees of Telecom Sector however it can be extended to the other organizations as well e.g., banking sector, insurance companies and construction companies etc.

\section{References}

Allen, T. D., Eby, L. T., Poteet, M. L., Lentz, E. \& Lima, L. (2004). Career Benefits Associated with Mentoring for Protégés: A Met analysis. Journal of Applied Psychology, 89, 127-136.

Barney, J. B. (1991). Firm resources and sustained competitive advantage. Journal of Management, 17, 99-120.

Baruch, Y. (2006). Career development in organizations and beyond: balancing traditional and contemporary viewpoints. Human Resource Management. Rev. 16(2), 125-138.

Bryant, S. E. \& Terborg, J. R. (2008). Impact of peer mentoring training on creation and sharing organizational knowledge. J. Manage. Iss. 20(1), 11-29.

Carter, S. (1994). The Development, Implementation and Evaluation of a Mentoring Scheme. Industrial and Commercial Training, 26(7), 16-23.

Chaplain, R. P. (1995). Stress and job satisfaction: A study of English primary school teachers. Educational Psychology, 15, 473-490.

Cotton, J. \& Tuttle, J. (1986). Employee turnover: A meta-analysis and review with implication for research. Academy of Management Review, 11 (1), 55-70.

Dawn, A. \& Palmer, E. (2009). Mentoring circles in higher education. Higher Educ. Res. Dev, 28(2), 125-136.

Gephart, M. A., Marsick, V. J., Van Buren, M. E. \& Spiro, M. S. (1996). Learning organizations come alive. Training and Development, 50(12), 34-36.

Gibb, S. \& Megginson, D. (1993). Inside Corporate Mentoring Schemes: A New Agenda of Concerns. Personnel Review, 22(1), 40-54.

Huselid, M. A. (1995). The Impact of Human Resource Management Practices on Turnover, Productivity, and Corporate Financial Performance. Academy of Management Journal, 38, 635-672.

Klasen, N. \& Clutterbuck, D. (2001). Implementing mentoring schemes, a practical guide to successful programs. Oxford: Butterworth- Heinemann.

Laukau, M. J. \& Scandura, T. A. (2002). An Investigation of Personal Learning in Mentoring Relationships: Contents, Antecedents and Consequences. Academy of Management Journal, 45(4), 779-790.

Lentz, E. (2004). The Link between the Career Plateau and Mentoring- Addressing the Empirical Gap. M. A. Thesis, Department of Psychology, College of Arts and Sciences, University of South Florida.

Lentz, E. \& Allen, T. D. (2009). The Role of mentoring others in the Career Plateauing Phenomenon. Group \& Organizational Management, 34(3), 358-384.

Leslie, K., Lingard, L. \& Whyte, S. (2005). Junior faculty experiences with informal mentoring. Medical Teach, 27(8), 693-698.

Levenson, A. R., Van der Stede, W. A. \& Cohen, S. G. (2006). Measuring the Relationship between Managerial Competencies and Performance. Journal of Management, 32(3), 360-380.

Lips-Wiersma, M. \& Hall, D. T. (2007). Organizational career development is not dead: A case study on managing the new career during organizational change. Journal of Organizational Behavior, 28, 771792.

Marsick, V. J. \& Watkins, K. E. (1999). Facilitating Learning Organization. Gower, Brookfield, VT.

Megginson, D., Clutterbuck, D., Garvey, B., Stokes, P., Garret-Harris, R. (2006). Mentoring in action: a practical guide. 2nd ed. Philadelphia, PA: Kogan.

Morrison, A. \& Von, G. M. (1990). 'Women and Minorities in Management', American Psychologist, 45, 200208. 
Olian, J., Giannantonio, C. \& Carrol, S. (1985). Managers' Evaluations of the Mentoring Process: The Protégé's Perspective. Paper presented at the Midwest Academy of Management meetings, St. Louis, MO.

Pedler, M., Burgoyne, J. \& Boydell, T. (1991). The learning Company. London: McGraw-Hill.

Pfeffer, J. (1994). Competitive Advantage through people: Unleashing the power of the work force. Boston: Harvard Business Press.

Phillips-Jones, L. (1982). Mentors and Protégés. New York: Arbour House.

Ragins, B. \& Cotton, J. (1991). Easier said than done: Gender Differences in Perceived Barriers to Gaining a Mentor. Academy of Management Journal, 34, 939-951.

Ragins, B. R., Cotton, J. L. \& Miller, J. S. (2000). Marginal Mentoring the Effects of Type of Mentor, Quality of Relationship and Programs Design on Work and Career Attitudes. Academy of Management Journal, 43(6), 1177-1194.

Ragins B. \& Scandura T. (1994). Gender Differences in Expected Outcomes of Mentoring Relationships. Academy of Management Journal, 37(4), 957-971.

Sari, H. (2004). An analysis of burnout and job satisfaction among Turkish special school head teachers and teachers, and the factors effecting their burnout and job satisfaction. Educational Studies, 30, 291306.

Scandura, T. (1992). Mentorship and Career Mobility: An Empirical Investigation. Journal of Investigative Behavior, 13, 169-174.

Senge, P. (1990). The fifth discipline Doubleday, New York.

Swickert, R. J., Rosentreter, C. J., Hittner, J. B. \& Mushrush, J. E. (2002). Extraversion, social support processes, and stress. Personal and Individual Differences, 32, 877-891.

Templeton, G., Lewis, B. \& Snyder, C. (2002). Development of a measure for the organizational learning construct. Journal of Management Information Systems, 19(2), 175-218.

Van Emmerik, I. J. H. (2008). It is not only Mentoring: the Combined Influences of Individual-level and Teamlevel Support on Job Performance. Career Development International, 13(7), 575-593.

Xianting, Y. \& Fungfai, N. (2010). Learning Organization and Mentoring Practice: An Empirical Investigation. 17th Annual European Real Estate Society Conference in Milan, Italy.

Zakaria, S. \& Yusoff, W. F. W. (2011). Transforming Human Resources into Human Capital, Information Management and Business Review, 2(2), 48-54. 